УДК [633.112.1«321»:581.132]

(C) 2013

Рожков А. О., кандидат сільськогосподарських наук, Пузік В. К., доктор сільськогосподарських наук

Харківський національний аграрний університет ім. В.В.Докучаєва

\title{
ДИНАМІКА ФОРМУВАННЯ ПІГМЕНТНИХ РЕЧОВИН У ЛИСТКАХ РОСЛИН ПШЕНИЦІ ТВЕРДОЇ ЯРОЇ ЗА ДІЇ РІЗНИХ ВАРІАНТІВ ЦЕНОТИЧНОЇ НАПРУГИ МІЖ РОСЛИНАМИ В ПОСІВАХ
}

\section{Рецензент - доктор сільськогосподарських наук, профессор П. В. Писаренко}

Представлені результати трирічних досліджень (2008-2010 рр.) щодо визначення динаміки формування пітментів фотосинтезу в рослинах пшеничі твердої ярої сорту Харківська 41 за дї різних варіантів способу сівби та норм висіву насіння. Встановлено значний вплив досліджуваних елементів технології на вміст хлорофілів $і$ каротиноїдів у листках рослин. Більших змін вміст пігментів фотосинтезу зазнавав за дї фактора норми висіву. Загальною закономірністю було зменшення вмісту хлорофілів і каротиноїдів у листках рослин за умови зменшення норми висіву та оптимізації розподілу рослин за площею живлення. Виявлено, щуо проведення сівби смуговим способом дає змогу проводити ї̈ в більш широкому діапазоні норм висіву без істотного зменшення вмісту пітментів фотосинтезу в листовій масі рослин. У ході досліджень визначено пряму кореляційну залежність між вмістом пітментів $і$ зерновою продуктивністю колоса головного пагона рослин.

Ключові слова: пшениця яра, способи сівби, норми висіву, хлорофіл а i b, каротиноїди, фенофази, онтогенез.

Постановка проблеми. Визначення динаміки накопичення пігментів у листках рослин має суттєве значення, поскільки їх вміст впливає на інтенсивність фотосинтезу та інші фізіологічні процеси. Дослідження спрямовані на вивчення динаміки накопичення й метаболізму пігментів фотосинтезу, особливості формування пігментного апарату листка в онтогенезі мають першочергове значення в оцінці впливу компонентів технологічних елементів на продуктивність рослин.

Аналіз основних досліджень і публікацій, у яких започатковано розв'язання проблеми. Створення сортів інтенсивного типу з високим потенціалом урожайності потребує поглибленого вивчення всіх елементів фотосинтетичної діяльності на різних рівнях організації асиміляційного апарату - від ценоза до клітин, хлоропластів $[6,12,13]$.

Гармонійний зв'язок фотосинтезу 3 іншими фізіологічними функціями рослин, насамперед із функціями росту й розвитку органів рослин, потребує формування загальної теорії продуктивності рослин $[4,14]$. Визначаючи подібну теорію, необхідно звернути увагу на фітомерний принцип організації структури пагона рослини $[7,10]$. В онтогенезі пшениці під впливом комплексу ендогенних факторів здійснюється постійна корекція міжметамерних відносин, що реалізується у функціях росту й розвитку елементів фітомерів і забезпечує в кінці «шукану» біологічну продуктивність.

У процесі фотосинтезу відбувається утворення органічних речовин. Для проходження фотосинтезу необхідна наявність у клітинах рослин пігментів - хлорофілів і каротиноїдів [3, 9]. Концентрація пігментів у структурі фотосинтетичного апарату рослин впливає на продуктивність та інтенсивність фотосинтезу, а отже, й на врожайність.

Обов'язковим компонентом фотосинтетичного апарату є каротиноїди, являючи собою похідні ізопрену, що складаються з 40 вуглецевих атомів. Усі функції жовтих пігментів остаточно ще не встановлені, однак не викликає сумніву, що вони здатні передавати енергію поглинутих квантів іншим пігментам, змінюючи спектр дії фотосинтетичного апарату, а також захищати хлорофіл від фоторуйнування [8].

Пігментний комплекс рослинного організму $є$ дуже чутливим до зміни умов навколишнього середовища $[2,5,11]$, тому його слід віднести до тих критеріїв, що визначають ступінь адаптації рослин до природніх й антропогенних чинників навколишнього середовища. Виявлення закономірностей зміни вмісту пігментного складу листків пшениці твердої ярої надасть можливість управління процесами розвитку посівів, формування органічної речовини рослинами та їх зернової продуктивності.

Мета досліджень полягала у встановленні впливу різних варіантів способів сівби та норм 
висіву рослин пшениці твердої ярої сорту Харківська 41 на зміну вмісту пігментів фотосинтезу в листках рослин, оскільки їхній вміст впливає на інтенсивність фізіологічних процесів, насамперед характеру проходження процесів фотосинтезу та формування зернової продуктивності посівів.

Методика досліджень. Дослід проводили в 2008-2010 pр. на дослідному полі ХНАУ імені В. В. Докучаєва за загальноприйнятою методикою [1]. Двофакторний дослід закладено методом спліт-плоту. Блокові ділянки у дослідах утворювали варіанти норм висіву: 450 нас./ $^{2}$; 500; 550 та 600 нас./м². Субділянками в досліді були такі способи сівби: 1 - рядковий, який проводили рядковою сівалкою С3-3,6; 2 - смуговий - сівалкою АПП-6 ВАТ «Фрегат». Сівалка АПП-6 забезпечувала розподіл насіння смугою $15 \mathrm{~cm}$ завширшки. Міжсмугова зона також становила в середньому 15 сантиметрів. Повторність у досліді триразова, площа посівної ділянки $-120 \mathrm{~m}^{2}$, облікової - $80 \mathrm{~m}^{2}$. Усі елементи технології вирощування (крім досліджуваних) були загальноприйнятими для східного Лісостепу України.

Грунт дослідного поля - чорнозем типовий важкосуглинковий на карбонатному лесі. В орному шарі грунту міститься 4,4-4,7 \% гумусу, 13,8 мг рухливого фосфору та 10,3 мг калію на 100 г грунту.

Район проведення досліджень характеризується нестабільним зволоженням. Кількість опадів за вегетацію рослин (березень - липень) у 20082010 рр. становила, відповідно, 314,1; 243,9 та 218,7 мм за середньобагаторічного показника 241,0 міліметрів. За кількістю опадів та їх розподілом найбільш сприятливим був вегетаційний період 2008 року.

Вміст пітментів фотосинтезу в листках рослин пиениці твердої ярої залежно від застосування різних способів сівби та норм висіву за фазами розвитку, мг/2 (середнс за 2008-2010 рр.)

\begin{tabular}{|c|c|c|c|c|c|c|c|c|c|c|c|c|c|}
\hline \multirow{3}{*}{$\begin{array}{c}\text { Фактор А } \\
\text { - норма } \\
\text { висіву, } \\
\text { шт./м }\end{array}$} & \multirow[b]{3}{*}{$\begin{array}{c}\text { Фактор В - } \\
\text { спосіб сівби* }\end{array}$} & \multicolumn{4}{|c|}{ Хлорофіл $a$} & \multicolumn{4}{|c|}{ Хлорофіл $b$} & \multicolumn{4}{|c|}{ Каротиноїди } \\
\hline & & \multicolumn{12}{|c|}{ фази росту й розвитку рослин } \\
\hline & & $\begin{array}{c}\text { ку- } \\
\text { щін- } \\
\text { ня }\end{array}$ & \begin{tabular}{|c|} 
вихід \\
у \\
труб- \\
ку
\end{tabular} & $\begin{array}{l}\text { коло- } \\
\text { сіння }\end{array}$ & $\begin{array}{l}\text { цві- } \\
\text { тін- } \\
\text { ня }\end{array}$ & $\begin{array}{l}\text { ку- } \\
\text { щін- } \\
\text { ня }\end{array}$ & $\begin{array}{c}\text { вихід } \\
\text { у } \\
\text { труб- } \\
\text { ку } \\
\end{array}$ & \begin{tabular}{|c|} 
ко- \\
ло- \\
сіння
\end{tabular} & $\begin{array}{c}\text { цві- } \\
\text { тін- } \\
\text { ня }\end{array}$ & $\begin{array}{l}\text { ку- } \\
\text { щін- } \\
\text { ня }\end{array}$ & $\begin{array}{c}\text { вихід } \\
\text { у } \\
\text { труб- } \\
\text { ку } \\
\end{array}$ & $\begin{array}{c}\text { ко- } \\
\text { ло- } \\
\text { сін- } \\
\text { ня } \\
\end{array}$ & $\begin{array}{l}\text { цві- } \\
\text { тіння }\end{array}$ \\
\hline \multirow{2}{*}{450} & 1 & 8,96 & 10,76 & & 11,00 & 3,12 & 3,46 & 3,48 & 3,44 & 2,82 & 3,29 & 3,38 & 3,33 \\
\hline & 2 & 9,08 & 10,80 & 10,92 & 11,06 & 3,13 & 3,45 & 3,51 & 3,49 & 2,82 & 3,30 & 3,46 & 3,38 \\
\hline \multirow{2}{*}{500} & 1 & 8,85 & 10,67 & 0,69 & 10,88 & 3,08 & 3,37 & 3,41 & 3,36 & 2,80 & 3,26 & 3,37 &, 31 \\
\hline & 2 & & 10,82 & 91 & 11,06 & 3,13 & 3,44 & 3,56 & 3,50 & 2,82 & 3,33 & 3,42 & \\
\hline \multirow{2}{*}{550} & 1 & & 10,46 & & & 3,0 & 3,33 & 3,31 & 3,24 & 2,72 &, 19 & 3,23 & \\
\hline & 2 & 8,98 & 10,71 & 10,84 & 11,00 & 3,11 & 3,42 & 3,53 & 3,47 & 2,78 & 3,24 & 3,39 & 3,31 \\
\hline & 1 & & 10,25 & 10,33 & 10,39 & 2,96 & 3,22 & 3,26 & 3,16 & 2,68 & 3,08 & 3,11 & 3,04 \\
\hline & 2 & 36 & 10,58 & 10,71 & 10,82 & 3,06 & 3,34 & 3,46 & 3,35 & 2,78 & 3,20 & 3,26 & 3,21 \\
\hline \multirow{4}{*}{$\begin{array}{c}\text { Середнє } \\
\text { за фак- } \\
\text { тором А }\end{array}$} & & 9,02 & 10,78 & 10,86 & 11,03 & 3,13 & 3,46 & 3,50 & 3,47 & 2,82 & 3,30 & 3,42 & 3,36 \\
\hline & 50 & 8,93 & 10,75 & 10,80 & 10,97 & 3,11 & 3,41 & 3,48 & 3,43 & 2,81 & 3,30 & 3,40 & 3,33 \\
\hline & 55 & 8,90 & 10,59 & 10,70 & 10,86 & 3,07 & 3,37 & 3,42 & 3,35 & 2,75 & 3,22 & 3,31 & 3,24 \\
\hline & 60 & 8,75 & 10,42 & 0,52 & 10,61 & 3,01 & 3,28 & 3,36 & 3,25 & 2,73 & 3,14 & 3,19 & 3,13 \\
\hline \multirow{2}{*}{$\begin{array}{c}\text { Середнє } \\
\text { за фак- } \\
\text { тором В }\end{array}$} & 1 & 8,82 & 10,54 & 10,59 & 10,75 & 3,05 & 3,35 & 3,36 & 3,30 & 2,75 & 3,21 & 3,28 & 3,21 \\
\hline & 2 & 8,98 & 10,73 & 10,84 & 10,98 & 3,11 & 3,41 & 3,52 & 3,45 & 2,80 & 3,27 & 3,38 & 3,32 \\
\hline \multicolumn{2}{|c|}{ Середнє за дослідом } & 8,90 & 10,63 & 10,72 & 10,87 & 3,08 & 3,38 & 3,44 & 3,38 & 2,78 & 3,24 & 3,33 & 3,26 \\
\hline \multicolumn{2}{|c|}{$\begin{array}{c}\mathrm{HIP}_{05} \text { головного ефекту } \\
\mathrm{A} \\
\end{array}$} & 0,08 & 0,17 & 0,15 & 0,12 & 0,03 & 0,08 & 0,06 & 0,06 & 0,10 & 0,03 & 0,09 & 0,06 \\
\hline \multicolumn{2}{|c|}{$\begin{array}{c}\mathrm{HIP}_{05} \text { головного ефекту } \\
\mathrm{B}\end{array}$} & 0,10 & 0,08 & 0,13 & 0,14 & 0,04 & 0,03 & 0,08 & 0,07 & 0,03 & 0,03 & 0,06 & 0,06 \\
\hline \multicolumn{2}{|c|}{$\begin{array}{c}\text { HIP }_{05} \text { часткових } \\
\text { порівнянь } \mathrm{A}\end{array}$} & 0,12 & 0,23 & 0,21 & 0,17 & 0,04 & 0,11 & 0,09 & 0,09 & 0,15 & 0,04 & 0,13 & 0,09 \\
\hline \multicolumn{2}{|c|}{$\begin{array}{c}\text { HIP }_{05} \text { часткових } \\
\text { порівнянь В }\end{array}$} & 0,19 & 0,15 & 0,26 & 0,29 & 0,07 & 0,06 & 0,16 & 0,14 & 0,06 & 0,07 & 0,11 & 0,12 \\
\hline
\end{tabular}

* Примітка. Способи сівби: 1 - рядковий; 2 - смуговий 
Температурний режим періоду вегетації за роками досліджень істотно відрізнявся від середньобагаторічних показників. Встановлені перевищення температурного режиму вносили значні корективи на хід росту й розвитку рослин, формування їхньої зернової продуктивності. Водночас із тим значна розбіжність за основними метеопоказниками протягом років досліджень дала змогу більшою мірою визначити вплив досліджуваних факторів на вміст пігментів фотосинтезу у листках рослин досліджуваного сорту пшениці ярої.

Результати досліджень. Аналіз впливу досліджуваних агротехнічних факторів свідчить, що більших змін показник вмісту пігментів у листках рослин зазнавав за різних норм висіву. Ця закономірність була відзначена за всіма фазами розвитку, в які проводили визначення. Так, якщо у фазу цвітіння концентрація хлорофілу $a$ у середньому за три роки досліджень за дії фактора А (норма висіву) коливалася від 10,61 до 11,03 мг/г (діапазон зміни ознаки $-4,0 \%$ ), то за дії фактора В (спосіб сівби) - лише від 10,75 до 10,98 мг/Г (діапазон зміни показника 2,1\%). $\mathrm{y}$ цю фазу концентрація хлорофілу $b$ за різних норм висіву коливалася в межах $6,5 \%$ за різних способів лише у межах 4,5 \% - від 3,25 до 3,47 мг/Г від 3,30 до 3,45 мг/г відповідно (див. табл.).

Аналогічна закономірність більшої значимості фактора норми висіву для концентрації хлорофілів $a$ i $b$ за всіма фазами розвитку була відзначена і безпосередньо за всіма роками досліджень.

Аналіз взаємодії досліджуваних елементів технології показав, що ефект оптимізації розподілу рослин за площею живлення на варіабельність показників вмісту хлорофілів у листках рослин пшениці твердої ярої значною мірою зумовлювався вибором тієї чи іншої норми висіву насіння. За меншої норми висіву ефект оптимізації розподілу насіння за площею живлення був значно нижчим. Наприклад, якщо вміст хлорофілу $a$ у середньому за роками досліджень у фазу виходу у трубку в разі застосування смугового способу сівби у варіантах із нормою висіву 450 нас./ $\mathrm{m}^{2}$ збільшувався на $0,04 \mathrm{мг} / \Gamma$, то на варіантах із нормою висіву 600 нас. $/ \mathrm{M}^{2}-$ на $0,33 \mathrm{мг} / \Gamma$ за $\mathrm{HIP}_{05}$ 0,26 мг/г (рис. 1). У фазу цвітіння проведення сівби смуговим способом забезпечувало збільшення вмісту хлорофілу $a$ порівняно з рядковим способом сівби на $0,06 \mathrm{Mг} / \Gamma-$ на варіантах із нормою висіву $450 \mathrm{Hac.} / \mathrm{m}^{2}$ і на $0,43 \mathrm{мг} / \Gamma-$ на варіантах із максимально досліджуваною нормою висіву $600 \mathrm{наc.} / \mathrm{m}^{2}$ за $\mathrm{HIP}_{05}$ часткових порівнянь фактора В 0,19 мг/г.
Вміст хлорофілу $b$ за дії фактора В також більших змін зазнавав на варіантах із максимальною нормою висіву 600 нас./м². Встановлена залежність переважно проявлялася в більш пізні фази росту - колосіння та цвітіння (рис. 1).

$\mathrm{У}$ цілому найвищий вміст хлорофілу $a$ i $b$ за всіма фазами росту був у варіантах із най-

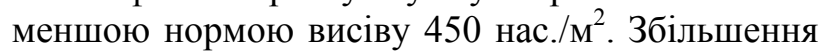
норми висіву спричиняло значне зменшення показників вмісту хлорофілів на варіантах рядкової сівби в усі фази росту. У той же час за смугового способу сівби збільшення норми висіву з 450 до 550 нас. $/ \mathrm{M}^{2}$ не приводило до істотного зменшення показників вмісту хлорофілів у всі фази визначень, що забезпечувало нормальне проходження фізіологічних процесів фотосинтезу без істотного зниження їхньої інтенсивності.

Пшениця тверда яра порівняно 3 іншими зерновими колосовими характеризувалася більш високим вмістом каротиноїдів як у листовій маci, так і в зерні, до того ж досліджуваний сорт Харківська 41 характеризувався вищим вмістом каротиноїдів із-поміж ярих пшениць.

Максимальний вміст каротиноїдів у середньому за три роки досліджень у листовій масі рослин пшениці спостерігався у фазу колосіння. У середньому за дослідом вміст каротиноїдів у фазу кущіння становив 2,78 мг/г сухої речовини; виходу у трубку $-3,24$ мг/г; колосіння - 3,33 мг/г, цвітіння $-3,26 \mathrm{мг/ \Gamma} \mathrm{(див.} \mathrm{табл.).}$

Ефект досліджуваних елементів технології на вміст каротиноїдів у листках рослин пшениці твердої ярої був найвищим у більш пізні фази росту й розвитку. Так, розбіжність показників вмісту каротиноїдів залежно від норми висіву у фазу кущіння у середньому за три роки досліджень становила близько $3,0 \%$, у фазу виходу у трубку $-5,0 \%$, колосіння $-7,0 \%$ і цвітіння майже 7,5\%. Ефект способу сівби на варіабельність вмісту каротиноїдів також був найбільшим у фази колосіння та цвітіння.

Перевага смугового способу сівби відносно впливу на концентрацію каротиноїдів порівняно із рядковим способом сівби поступово зростала у міру збільшення норми висіву насіння (див. табл.). Так, у фазу колосіння вміст каротиноїдів за умови застосування смугового способу сівби зростав порівняно з варіантами, де сівбу проводили рядковою сівалкою, на 0,08 мг/г $(2,4 \%)$ у варіантах із нормою висіву 450 нас./ $\mathrm{m}^{2}$ i на 0,15 мг/Г (4,8 \%) - у варіантах із найбільшою нормою висіву -600 нас. $/ \mathrm{M}^{2}$ за НІР 05 часткових порівнянь ефекту фактора $\mathrm{B}-0,12$ мг/г. Таким чином, смуговий спосіб сівби дає змогу застосову- 


\section{СІЛЬСЬКЕ ГОСПОДАРСТВО. РОСЛИННИЦТВО}

вати норму висіву в більш широкому діапазоні без істотного зменшення концентрації пігментів фотосинтезу.

Так само ефект підвищення норми висіву на зменшення вмісту каротиноїдів був значно вищим на варіантах із застосуванням рядкового способу сівби. Наприклад, у фазу колосіння за умови збільшення норми висіву 3450 до 600 нас./ м $^{2}$ вміст каротиноїдів у середньому за три роки дослі-

\section{Хлорофіл $\boldsymbol{a}$}

джень зменшувався 3 3,38 до 3,11 мг/г (або майже на 9,0 \%) за рядкового способу сівби і лише 3 3,46 до 3,26 мг/г (або на 6,0 \%) - за смугового способу сівби.

Співвідношення між сумарним вмістом хлорофілів і каротиноїдами у середньому по досліду у фази кущіння, виходу у трубку, колосіння та цвітіння становило 4,3:1,0; 4,3:1,0;4,2:1,0 та 4,4 до 1,0 відповідно.

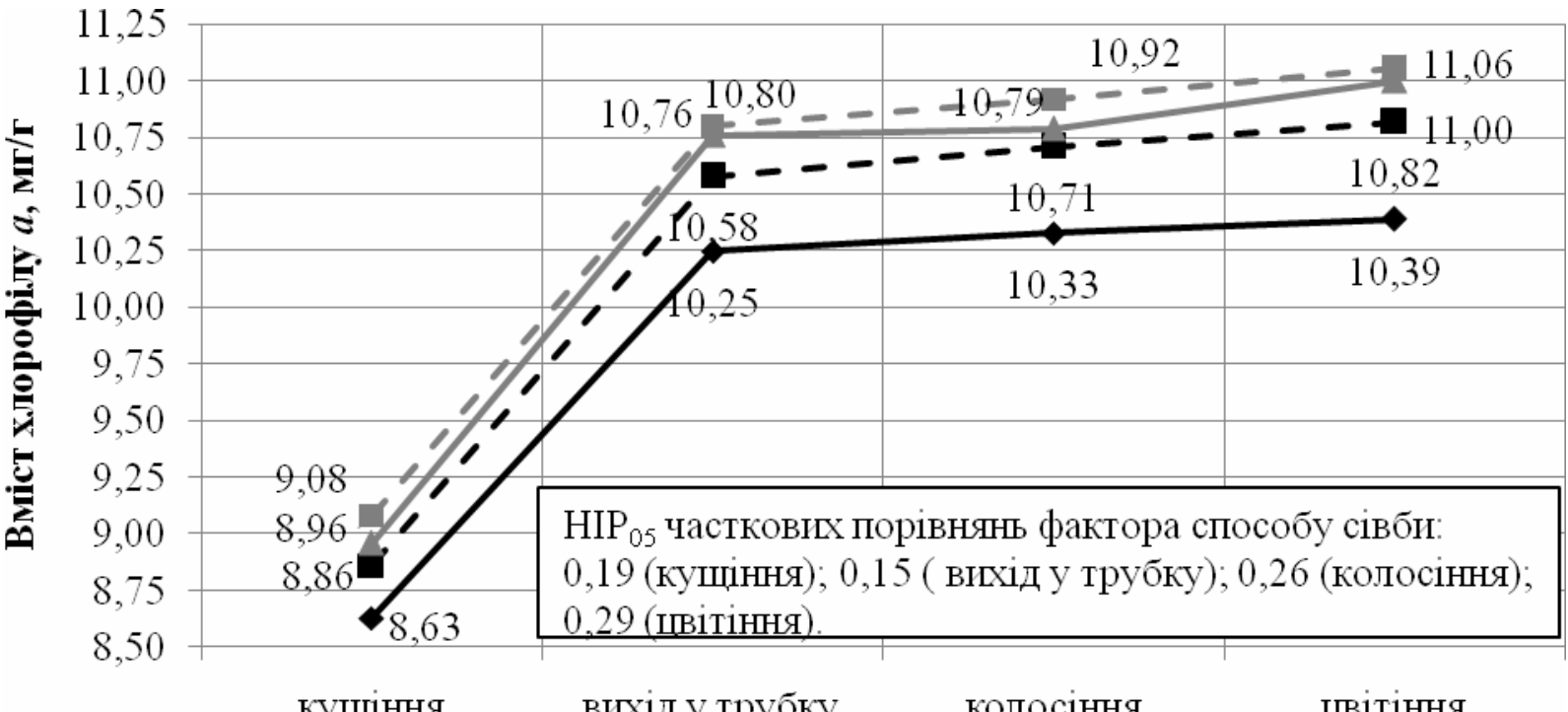

кущіння

вихід у трубку

колосінНЯ

цвітіння

\section{Фази росту й розвитку}

\section{Хлорофіл $b$}

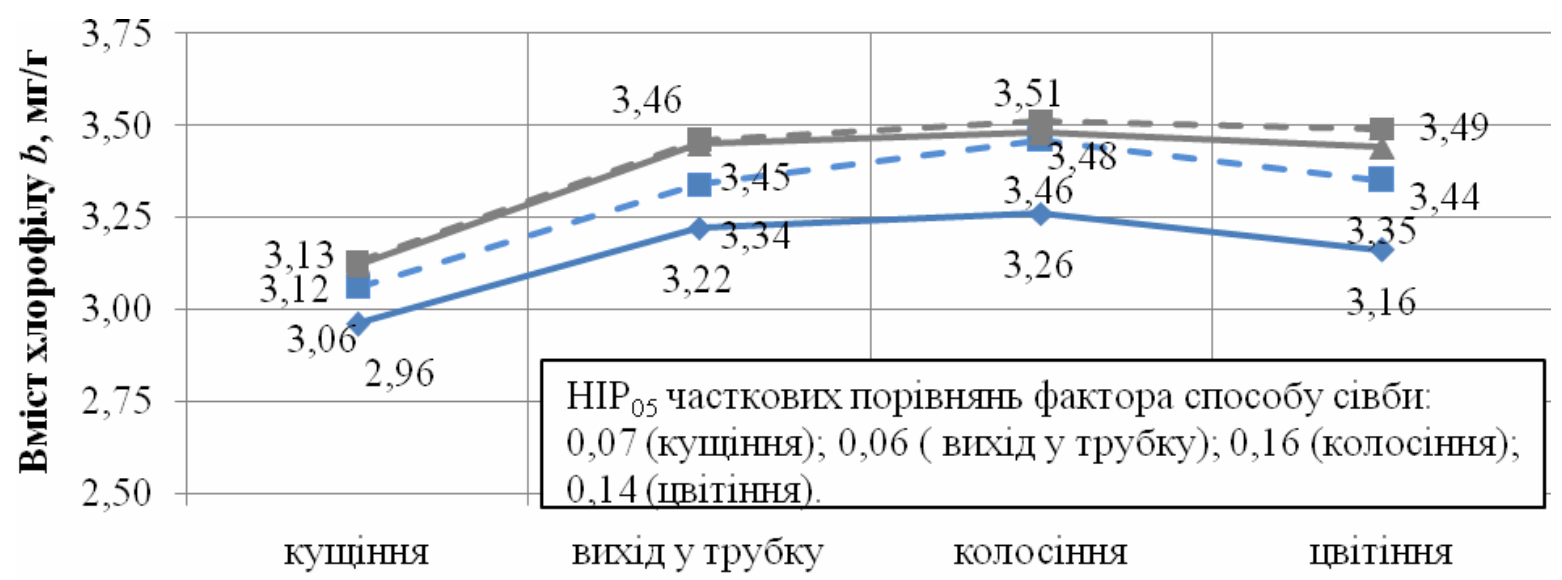

Фази росту й розвитку

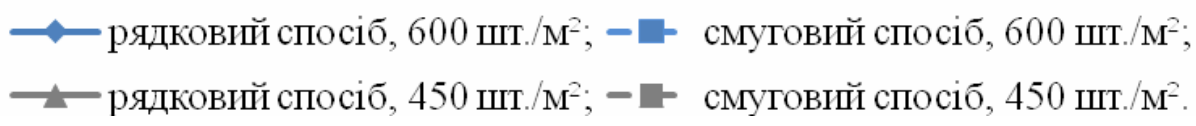

Рис. 1. Динаміка вмісту хлорофілів у листках рослин пшениці твердої ярої за фазами розвитку залежно від застосування різних варіантів способу сівби та норм висіву (середне за 2008-2010 рр.) 


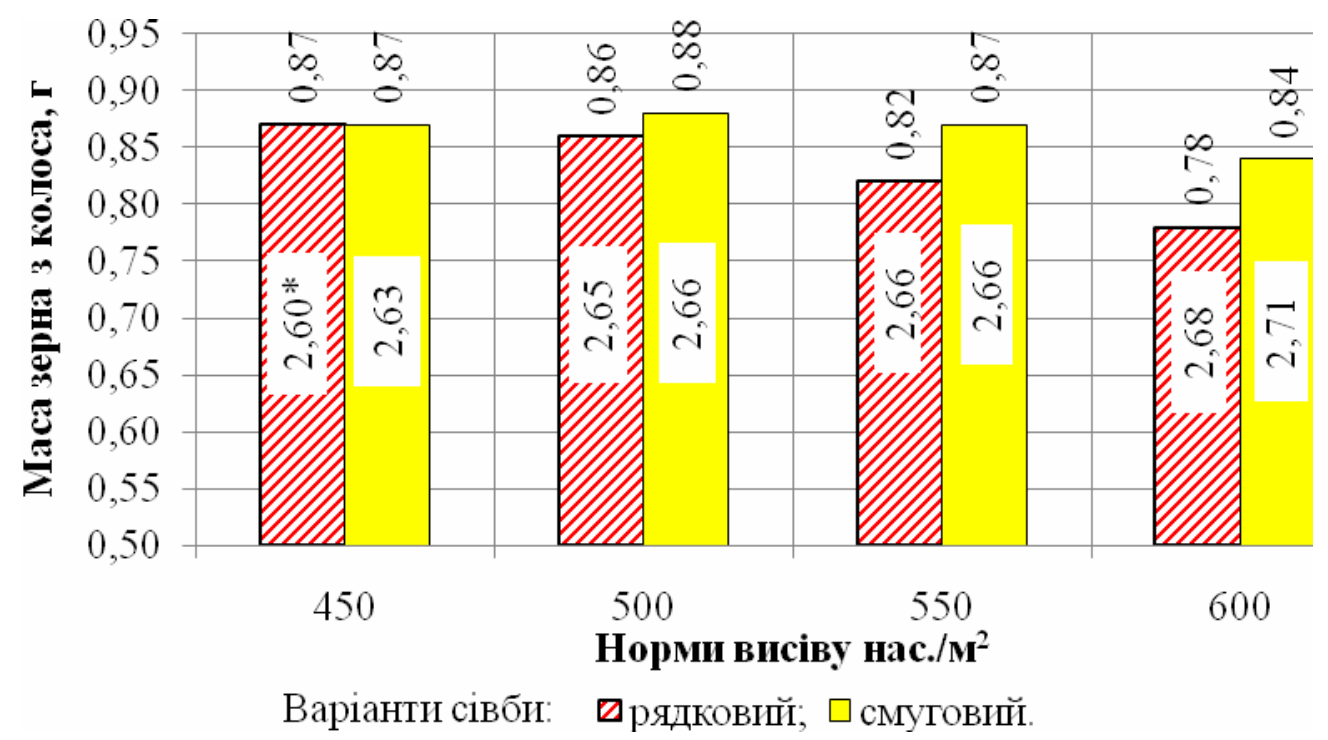

* У середині стовбиів вказаний індекс листової поверхні відповідних варіантів досліджень.

\section{Рис. 2. Маса зерна з головного колосу та індекс листової поверхні рослин пшениці твердої ярої за дії різних норм висіву та способів сівби (середнс за 2008-2010 рp.)}

У проведеному досліді між сумарним вмістом хлорофілів та площею листків за досліджуваних варіантів норм висіву спостерігалася тісна зворотня лінійна регресія $\mathrm{y}=19,93122-2,24670 \mathrm{x}-$ на рядкових посівах і $\mathrm{y}=16,33853-0,66354 \mathrm{x}-$ на смугових посівах. Коефіцієнт кореляції між сумарним вмістом хлорофілів та індексом листової поверхні становив 0,917 на варіантах рядкового способу і 0,794 - на варіантах смугового способу сівби.

Відповідно до розрахованих рівнянь регресії, збільшення індексу площі листя на 0,1 , що відбувається за умови підвищення норми висіву, зменшувало сумарний вміст хлорофілів на 0,25 мг/г у варіантах рядкової сівби і лише на $0,07 \mathrm{мг/ \Gamma -3а}$ смугової сівби.

У ході проведених досліджень було встановлено аналогічну закономірність впливу досліджуваних елементів технології вирощування як на зернову продуктивність окремої рослини, так і на вміст хлорофілів $a$ і $b$. Найбільша маса зерна 3 колосу рослин пшениці твердої ярої у середньому за три роки досліджень була у варіантах із меншою ценотичною напругою у посівах (рис. 2).

\section{БІБЛІОГРАФІЯ}

1. Доспехов Б. А. Методика полевого опыта / Б. А. Доспехов. - М. : Агропромиздат, 1985. $351 \mathrm{c}$.

2. Ермаков А. И. Методы биохимических исследований растений / А. И. Ермаков, В. В. Арасимович, Н. П. Ярош. - Л. : Агропромиздат, 1987. $430 \mathrm{c}$.
Сумарний вміст хлорофілів $a$ і $b$ мав тісний прямий кореляційний зв'язок із масою зерна 3 колосу рослин пшениці твердої ярої $(\mathrm{r}=0,987)$. Зв'язок між масою зерна 3 колосу та сумарним вмістом хлорофілів $a$ і $b$ апроксимувався наступним рівнянням лінійної регресійної залежності $\mathrm{y}=-0,516576+0,095871 \mathrm{x}$, яке в межах досліджуваних варіантів діє у $97,4 \%$ випадків $\left(\mathrm{r}^{2}=\right.$ 0,974).

Висновок. Вміст пігментів фотосинтезу в листках рослин пшениці твердої зазнає істотних змін залежно від характеру розподілу рослин за площею живлення та густоти посіву. Смугова сівба надає можливість проводити сівбу в ширшому діапазоні норми висіву без істотного зниження вмісту пігментів фотосинтезу в листках рослин. Впливу норм висіву та способів сівби на зміну співвідношення між вмістом хлорофілів і каротиноїдів фактично не спостерігалося. Дослідженнями доведено тісну кореляційну залежність між сумарним вмістом хлорофілу $a$ і $b$ та зерновою продуктивністю колосу головного пагона $(\mathrm{r}=0,987)$.

3. Жученко А. А. Адаптивное растениеводство (эколого-генетические основы) / А. А. Жученко. - Кишинев : Штиинца, 1990. - 432 с.

4. Макроносов A. T. Онтогенетический аспект фотосинтеза. - М. : Наука, 1981. - 195 с.

5. Мусієнко М. М. Спектрометричні методи в практиці фізіології, біохімії та екології рослин / 
М. М. Мусієнко, Т. В. Паришкова, П. С. Славний. - К. : Фітоцентр, 2001. - 199 с.

6. Ничипорович A. А. Физиология фотосинтеза и продуктивность растений / А. А. Ничипорович // Физиология фотосинтеза. - М. : Наука, 1982. C. 7-33.

7. Степанов С. А. Проблема целостности растения на современном этапе развития биологии / С. А. Степанов // Изв. СГУ. Серия «Химия, биология, экология». - Вып. 2. - Саратов, 2008. T. 8. - C. 50-57.

8. Тарчевский И. А. Основы фотосинтеза [учеб. пособие для биол. спец. вузов] / И. А. Тарачевский. - М. : Высш. шк., 1977. - 253 с.

9. Удовенко Г. В. Методы оценки устойчивости растений к неблагоприятным условиям среды / Г. В. Удовенко. - Л. : Колос, 1976. - 318 с.

10. Шафронова Л. М. Растение как жизненная форма (к вопросу о содержании понятия «расте- ние») / Л. М. Шафранова // Журн. общей биол. M., 1990. - T. 51. - №1. - C. 72-88.

11. Kreuz K. Old enzynes for a new job / K. Kreuz, R. Tommasins, E. Martinoa // Plant Physiol. - 1996. III. - P. 349-353.

12. Robertson E. I. Significant Changes in Cell and Chloroplast Development in Young Wheat leawes (Triticumaestivum w Hereward) Grown in Elevated $\mathrm{CO}_{2}$ / E. I. Robertson, M. Rachel, R. M. Leech // Plant Physiol., 1995. - Vol. 107. - P. 63-71.

13. Sims D. A. Relationships between leaf pigment content and spectral reflectance across a wide range of species. Leaf structures and developmental stages / D. A. Sims, I. A. Gramon // Remote Sinsing of Environment, 2002. - Vol. 81. - P. 337-354.

14. Thomas $H$. Chlorophyll: a symptom and a regulator of plastid development / H. Thomas // New Phytologist, 1997. - Vol. 136. - P. 163-181. 